\title{
Association analysis between SNPs in LATS1 and LATS2 and non-cardia gastric cancer
}

Li-cong Ma ${ }^{1,2,3+}$, Xu-yang Tian ${ }^{1,2+}$, Fang Gao ${ }^{4}$, Wen-jie Dong ${ }^{3}$, Tong Dang ${ }^{1 *}$ and Yan-bin Jia ${ }^{1,3,5^{*}}$

\begin{abstract}
Background: Many studies have found that large tumor suppressor kinase 1 (LATS1) and LATS2 play important roles in many diseases, but studies have been rare on the relationship between these genes and non-cardia gastric cancer (GC). We performed a case-control association study to investigate the associations between single nucleotide polymorphisms (SNPS) in LATS1 and LATS2 genes and Helicobacter pylori (H. pylori) infection as well as the risk of non-cardia GC.

Methods: First, H. pylori infection was determined by the serological test using enzyme-linked immunoassay. Then genotyping of SNPs was performed for 808 samples by the Taqman method. Finally, unconditional logistic regression was used to calculate the odds ratios (ORs) and 95\% confidence intervals (Cls), adjusted for age and gender, for the association of each SNP with the infection of $H$. pylori, the risk of non-cardia gastric cancer, as well as the expression of LATS1 and LATS2 proteins in non-cardia GC tissues, using the codominant, dominant, recessive, overdominant, and log-additive inheritance models, respectively.

Results: The statistical results showed that LATS2 rs9552315 was associated with H. pylori infection, and the CC + CT genotype could reduce the risk of $H$. pylori infection (odds ratio [OR]: 0.549, 95\% confidence interval [Cl]: 0.339$0.881, P<0.05)$ compared with the TT genotype in a dominant model. LATS1 rs9393175 was associated with the risk of non-cardia GC, and the AG genotype reduced the risk of non-cardia GC (OR: 0.702, 95\% Cl: 0.516-0.952, $P<0.05$ ) compared with the GG + AA genotype in an overdominant model. LATS2 rs9509492 was associated with the risk of GC in an log-additive model. No associations were found between five SNPs and expression of LATS1 and LATS2 proteins in non-cardia GC tissue.
\end{abstract}

Conclusions: LATS2 rs9552315 CT genotype may be a protective factor against infection of H. pylori. LATS1 rs9393175 AG genotype and LATS2 rs9509492 GG genotype may be protective factors for non-cardia GC.

Keywords: LATS1, LATS2, Non-cardia gastric cancer, Association study

\section{Background}

Gastric cancer (GC) is one of the most common malignant tumors with high morbidity, high mortality, and poor prognosis. In 2018, there were more than 1 million new cases of GC worldwide and 783,000 deaths caused

\footnotetext{
* Correspondence: dtong999@sina.com; jyb690318@hotmail.com 'Li-cong Ma and Xu-yang Tian contributed equally to this work. 'Inner Mongolia Institute of Digestive Diseases, The Second Affiliated Hospital of Baotou Medical College, 30 Hudemulin Street, Baotou 014030, Inner Mongolia, China

Full list of author information is available at the end of the article
}

by GC. The morbidity and mortality rate ranked fifth and third among all malignant tumors, respectively, and it was one of the malignant tumors that seriously affected human health [1]. Helicobacter pylori (H. pylori) infection is a main cause of GC. According to the epidemiological investigation, about $78 \%$ of GC patients have been infected with $H$. pylori [2]. It is closely related to the pathogenesis of GC and was defined as a class I carcinogen of the stomach by the International Agency for Research on Cancer in 1994 [3]. It has been reported in the literature that about $74.7-89.0 \% \mathrm{GC}$ is associated

C C The Author(s). 2020 Open Access This article is licensed under a Creative Commons Attribution 4.0 International License, which permits use, sharing, adaptation, distribution and reproduction in any medium or format, as long as you give appropriate credit to the original author(s) and the source, provide a link to the Creative Commons licence, and indicate if changes were made. The images or other third party material in this article are included in the article's Creative Commons licence, unless indicated otherwise in a credit line to the material. If material is not included in the article's Creative Commons licence and your intended use is not permitted by statutory regulation or exceeds the permitted use, you will need to obtain permission directly from the copyright holder. To view a copy of this licence, visit http://creativecommons.org/licenses/by/4.0/. The Creative Commons Public Domain Dedication waiver (http://creativecommons.org/publicdomain/zero/1.0/) applies to the data made available in this article, unless otherwise stated in a credit line to the data. 
Table 1 Comparison of general conditions of 808 samples

\begin{tabular}{|c|c|c|c|c|c|}
\hline \multirow[t]{2}{*}{ Variable } & & \multicolumn{2}{|l|}{ Group } & \multirow[t]{2}{*}{ Statistics } & \multirow[t]{2}{*}{ P } \\
\hline & & Case $(n=381)$ & Control $(n=427)$ & & \\
\hline Age (median (IQR)) & & $60(52-69)$ & $57(50-65)$ & $W=65,012$ & $<0.001$ \\
\hline \multirow[t]{2}{*}{ Age group } & $<65$ & $237(62.2 \%)$ & $313(73.3 \%)$ & $x 2=11.408$ & $<0.001$ \\
\hline & $\geq 65$ & $144(37.8 \%)$ & $114(26.7 \%)$ & & \\
\hline \multirow[t]{2}{*}{ Gender } & female & 95 (24.9\%) & $107(25.1 \%)$ & $x^{2}=0.002$ & 0.968 \\
\hline & male & $286(75.1 \%)$ & $320(74.9 \%)$ & & \\
\hline
\end{tabular}

with $H$. pylori [4]. However, although about $50 \%$ of the world's population is infected with $H$. pylori, only $1-3 \%$ eventually develop GC. This suggests that individual genetic factors of the host play important roles in the development of GC [5, 6]. Many literature reports and previous studies from our research group found that the single nucleotide polymorphisms (SNPs) of some genes are associated with $H$. pylori infection and GC [7].

Large tumor suppressor kinase 1 (LATS1) and LATS2 are tumor suppressor proteins that have been discovered in recent years [8]. They are the core components of the Hippo signaling pathway and regulate a series of biological behaviors through phosphorylation reactions with components upstream and downstream of the pathways including cell proliferation, differentiation, apoptosis, and regulation of organ size [9-11]. Studies have reported that the expression levels of LATS1 and LATS2 proteins in malignant tumor tissues such as ovarian tumors and non-small-cell lung carcinoma are significantly lower than those in normal tissues [12, 13]. Previous studies from our group confirmed that the expression levels of LATS1 and LATS2 proteins in GC tissues are significantly lower than those in normal gastric tissues [14]. Therefore, we speculated that LATS1 and LATS2 gene polymorphisms may be involved in the occurrence and development of GC. However, the association of LATS1 and LATS2 gene polymorphisms with non-cardiac GC carcinogenesis has not been reported.

Therefore, this case-control association study was performed in the Baotou Han population to investigate the association between five SNPs of LATS1 and LATS2 genes and H. pylori infection and non-cardia GC.

\section{Methods \\ Subjects}

We collected 381 blood samples from non-cardia GC patients from Baotou Cancer Hospital (Inner Mongolia, China) from 2008 to 2017, of which 288 cases were collected from June 2008 to December 2010, and the remaining 93 cases were collected from 2015 to 2017. During the same period the patients were recruited, our group collected 427 blood samples from normal medical examinations in the First Affiliated Hospital of Baotou Medical College and Inner Mongolia Baotou Steel Hospital. The inclusion criteria for the cases were as follows. The patients had to be of Han descent, and the three generations had no history of intermarriage with other ethnic groups and had been living in Baotou for more than 5 years at the time of onset. Secondary cases, relapse cases, and patients who had received chemotherapy or radiotherapy were excluded. All cases were confirmed by pathology examination. The normal control inclusion criteria were as follows. The medical examination was required to confirm Han descent, and the three generations had no history of marriage with other ethnic groups and had been living in Baotou for more than 5 years with no individual history of cancer or identifiable gastric or genetic disease. At recruitment, informed consent was obtained from each subject, and the study was approved by the Institutional Review Board of Baotou Medical College.

\section{H. pylori infection test}

The serological status of $H$. pylori infection was determined by an enzyme-linked immunosorbent assay (ELISA) using the "Human Helicobacter pylori antibody (HP-Ab) ELISA Kit (96-well plate)," which was

Table 2 General comparison in negative and positive cases of $H$. pylori infection

\begin{tabular}{|c|c|c|c|c|c|}
\hline \multirow[t]{2}{*}{ Variable } & & \multicolumn{2}{|c|}{ H. pylori infection of the control group } & \multirow[t]{2}{*}{ Statistics } & \multirow[t]{2}{*}{$P$} \\
\hline & & negative $(n=225)$ & positive $(n=202)$ & & \\
\hline Age (median (IQR)) & & $54(50-66)$ & $53(49-64)$ & $W=24,220$ & 0.240 \\
\hline \multirow[t]{2}{*}{ Age group } & $<65$ & $160(71.1 \%)$ & $153(75.7 \%)$ & $x 2=1.167$ & 0.280 \\
\hline & $\geq 65$ & $65(28.9 \%)$ & $49(24.3 \%)$ & & \\
\hline \multirow[t]{2}{*}{ Gender } & female & $56(24.9 \%)$ & $51(25.2 \%)$ & $x 2=0.007$ & 0.932 \\
\hline & male & $169(75.1 \%)$ & $151(74.8 \%)$ & & \\
\hline
\end{tabular}


Table 3 Association between 5 SNPs and risk of H. pylori infection under different genetic models

\begin{tabular}{|c|c|c|c|c|c|c|c|c|}
\hline Locus & Model & Genotype & Control [n(\%)] & Case $[n(\%)]$ & OR $(95 \% C l)^{a}$ & $P$ & AIC & $\mathrm{BIC}$ \\
\hline \multirow{10}{*}{$\begin{array}{l}\text { LATS1 } \\
\text { rs9393175 }\end{array}$} & \multirow[t]{3}{*}{ codominant } & $\mathrm{G} / \mathrm{G}$ & $125(55.56)$ & $128(64.00)$ & 1 & - & \multirow[t]{3}{*}{1092.330} & \multirow[t]{3}{*}{1115.760} \\
\hline & & $A / G$ & $88(39.11)$ & $61(30.50)$ & $0.671(0.443-1.010)$ & 0.057 & & \\
\hline & & $\mathrm{A} / \mathrm{A}$ & $12(5.33)$ & $11(5.50)$ & $0.916(0.383-2.175)$ & 0.842 & & \\
\hline & \multirow[t]{2}{*}{ dominant } & $\mathrm{G} / \mathrm{G}$ & $125(55.56)$ & $128(64.00)$ & 1 & - & \multirow[t]{2}{*}{591.691} & \multirow[t]{2}{*}{607.899} \\
\hline & & $A / A+A / G$ & $100(44.44)$ & $72(36.00)$ & $0.700(0.472-1.035)$ & 0.074 & & \\
\hline & \multirow[t]{2}{*}{ recessive } & $\mathrm{G} / \mathrm{G}+\mathrm{A} / \mathrm{G}$ & $213(94.67)$ & $189(94.50)$ & 1 & - & \multirow[t]{2}{*}{594.873} & \multirow[t]{2}{*}{611.081} \\
\hline & & $\mathrm{A} / \mathrm{A}$ & $12(5.33)$ & $11(5.50)$ & $1.062(0.449-2.487)$ & 0.889 & & \\
\hline & \multirow[t]{2}{*}{ overdominant } & $\mathrm{G} / \mathrm{G}+\mathrm{A} / \mathrm{A}$ & $137(60.89)$ & $139(69.50)$ & & - & \multirow[t]{2}{*}{591.254} & \multirow[t]{2}{*}{607.462} \\
\hline & & $A / G$ & $88(39.11)$ & $61(30.50)$ & $0.675(0.449-1.011)$ & 0.058 & & \\
\hline & log-additive & - & - & - & $0.792(0.570-1.093)$ & 0.158 & 592.876 & 609.084 \\
\hline \multirow{10}{*}{$\begin{array}{l}\text { LATS2 } \\
\text { rs558614 }\end{array}$} & \multirow[t]{3}{*}{ codominant } & $T / T$ & $63(29.30)$ & $60(30.46)$ & 1 & - & \multirow[t]{3}{*}{579.405} & \multirow[t]{3}{*}{599.511} \\
\hline & & $\mathrm{C} / \mathrm{T}$ & $106(49.30)$ & $91(46.19)$ & $0.900(0.572-1.416)$ & 0.648 & & \\
\hline & & $\mathrm{C} / \mathrm{C}$ & $46(21.40)$ & $46(23.35)$ & $1.042(0.606-1.794)$ & 0.881 & & \\
\hline & \multirow[t]{2}{*}{ dominant } & $T / T$ & $63(29.30)$ & $60(30.46)$ & 1 & - & \multirow[t]{2}{*}{577.742} & \multirow[t]{2}{*}{593.826} \\
\hline & & $\mathrm{C} / \mathrm{C}+\mathrm{C} / \mathrm{T}$ & $152(70.70)$ & $137(69.54)$ & $0.943(0.617-1.442)$ & 0.787 & & \\
\hline & \multirow[t]{2}{*}{ recessive } & $\mathrm{T} / \mathrm{T}+\mathrm{C} / \mathrm{T}$ & $169(78.60)$ & $151(76.65)$ & 1 & - & \multirow[t]{2}{*}{577.614} & 593.698 \\
\hline & & $\mathrm{C} / \mathrm{C}$ & $46(21.40)$ & $46(23.35)$ & $1.112(0.698-1.772)$ & 0.654 & & \\
\hline & overdominant & $\mathrm{T} / \mathrm{T}+\mathrm{C} / \mathrm{C}$ & 109 (50.70) & $106(53.81)$ & 1 & - & 577.428 & 593.512 \\
\hline & & $\mathrm{C} / \mathrm{T}$ & $106(49.30)$ & $91(46.19)$ & $0.884(0.599-1.303)$ & 0.534 & & \\
\hline & log-additive & - & - & - & $1.012(0.773-1.326)$ & 0.930 & 577.807 & 593.891 \\
\hline LATS2 & codominant & $T / T$ & $45(20.18)$ & $60(30.00)$ & 1 & - & 588.160 & 608.397 \\
\hline rs955<315 & & $C / T$ & $119(53.36)$ & $88(44.00)$ & $0.549(0.339-0.881)$ & 0.014 & & \\
\hline & & $\mathrm{C} / \mathrm{C}$ & $59(26.46)$ & $52(26.00)$ & $0.650(0.377-1.114)$ & 0.118 & & \\
\hline & dominant & $\mathrm{T} / \mathrm{T}$ & 45 (20.18) & $60(30.00)$ & 1 & - & 586.672 & 602.862 \\
\hline & & $\mathrm{C} / \mathrm{C}+\mathrm{C} / \mathrm{T}$ & $178(79.82)$ & $140(70.00)$ & $0.582(0.370-0.909)$ & 0.018 & & \\
\hline & recessive & $\mathrm{T} / \mathrm{T}+\mathrm{C} / \mathrm{T}$ & $164(73.54)$ & $148(74.00)$ & 1 & - & 592.331 & 608.521 \\
\hline & & $\mathrm{C} / \mathrm{C}$ & $59(26.46)$ & $52(26.00)$ & $0.970(0.626-1.499)$ & 0.891 & & \\
\hline & overdominant & $\mathrm{T} / \mathrm{T}+\mathrm{C} / \mathrm{C}$ & $104(46.64)$ & $112(56.00)$ & 1 & - & 588.616 & 604.805 \\
\hline & & $C / T$ & $119(53.36)$ & $88(44.00)$ & $0.685(0.466-1.005)$ & 0.054 & & \\
\hline & log-additive & - & - & - & $0.811(0.618-1.061)$ & 0.128 & 590.018 & 606.207 \\
\hline LATS2 & codominant & $\mathrm{C} / \mathrm{C}$ & 177 (80.09) & $173(85.64)$ & 1 & - & 590.953 & 611.190 \\
\hline rs/31/4/1 & & $C / T$ & 39 (17.65) & $28(13.86)$ & $0.746(0.435-1.266)$ & 0.281 & & \\
\hline & & $T / T$ & $5(2.26)$ & $1(0.50)$ & $0.206(0.011-1.230)$ & 0.152 & & \\
\hline & dominant & $\mathrm{C} / \mathrm{C}$ & 177 (80.09) & $173(85.64)$ & 1 & - & 590.590 & 606.780 \\
\hline & & $C / T+T / T$ & $44(19.91)$ & $29(14.36)$ & $0.684(0.405-1.143)$ & 0.151 & & \\
\hline & recessive & $\mathrm{C} / \mathrm{C}+\mathrm{C} / \mathrm{T}$ & $216(97.74)$ & $201(99.50)$ & 1 & - & 590.126 & 606.316 \\
\hline & & $\mathrm{T} / \mathrm{T}$ & $5(2.26)$ & $1(0.50)$ & $0.217(0.011-1.362)$ & 0.165 & & \\
\hline & overdominant & $\mathrm{C} / \mathrm{C}+\mathrm{T} / \mathrm{T}$ & $182(82.35)$ & $174(86.14)$ & 1 & - & 591.689 & 607.879 \\
\hline & & $C / T$ & 39 (17.65) & $28(13.86)$ & $0.764(0.446-1.295)$ & 0.320 & & \\
\hline & log-additive & - & - & - & $0.667(0.413-1.057)$ & 0.090 & 589.722 & 609.912 \\
\hline LATS2 & codominant & $\mathrm{A} / \mathrm{A}$ & 87 (39.01) & 74 (36.82) & 1 & - & 595.106 & 615.355 \\
\hline I59509492 & & $A / G$ & 98 (43.95) & $96(47.76)$ & $1.147(0.754-1.746)$ & 0.522 & & \\
\hline & & $\mathrm{G} / \mathrm{G}$ & $38(17.04)$ & $31(15.42)$ & $0.964(0.544-1.699)$ & 0.898 & & \\
\hline & dominant & $\mathrm{A} / \mathrm{A}$ & 87 (39.01) & 74 (36.82) & 1 & - & 593.488 & 609.687 \\
\hline
\end{tabular}


Table 3 Association between 5 SNPs and risk of H. pylori infection under different genetic models (Continued)

\begin{tabular}{|c|c|c|c|c|c|c|c|c|}
\hline Locus & Model & Genotype & Control [n(\%)] & Case $[n(\%)]$ & OR $(95 \% C l)^{a}$ & $P$ & AIC & $\mathrm{BIC}$ \\
\hline & & $\mathrm{A} / \mathrm{G}+\mathrm{G} / \mathrm{G}$ & $136(60.99)$ & $127(63.18)$ & $1.096(0.739-1.627)$ & 0.649 & & \\
\hline & \multirow[t]{2}{*}{ recessive } & $A / A+A / G$ & 185 (82.96) & $170(84.58)$ & 1 & - & 593.516 & 609.715 \\
\hline & & $\mathrm{G} / \mathrm{G}$ & $38(17.04)$ & $31(15.42)$ & $0.894(0.529-1.500)$ & 0.672 & & \\
\hline & \multirow[t]{2}{*}{ overdominant } & $\mathrm{A} / \mathrm{A}+\mathrm{G} / \mathrm{G}$ & $125(56.05)$ & $105(52.24)$ & 1 & - & 593.123 & 609.322 \\
\hline & & $A / G$ & $98(43.95)$ & $96(47.76)$ & $1.160(0.790-1.702)$ & 0.449 & & \\
\hline & log-additive & - & - & - & $1.013(0.772-1.329)$ & 0.927 & 593.687 & 609.886 \\
\hline
\end{tabular}

adjusted for gender and age

purchased from Suzhou Ailsa Bio-Technology Co., Ltd. (Suzhou, China).

\section{Screening for SNPs}

SNPs of the LATS1 and LATS2 genes were screened at the National Center for Biotechnology Information database, and the tag SNPs of the study genes were screened according to the Chinese Han genetic polymorphism data provided by the HapMap database (http://hapmap. ncbi.nlm.nih.gov/). The SNP minority allele frequency was required to be greater than $5 \%$, and the linkage disequilibrium (LD) $\left(\mathrm{r}^{2}\right)$ cut-off was required to be 0.8 . A total of five SNPs were screened including LATS1 rs9393175, LATS2 rs558614, rs9552315, rs7317471, and rs9509492.

\section{Genotyping assay}

Genomic DNA was extracted using the "TIANamp Blood DNA Kit, spin-column type (200 tests)", which was purchased from Tiangen Biotech (Beijing) Co., Ltd. Genotyping was performed by the TaqMan method. Primers and probes were designed by ABI Scientific Inc. (Sterling, VA, USA). The genotyping success rates of five SNPs were all more than $97.8 \%$. Failed genotypes were not repeated. In the experiment, 5\% of DNA samples with good quality and quantity were randomly selected for repeated experiments to verify the accuracy of the results. The consistency of genotyping results in all repeated samples was $100 \%$.

\section{Statistical analysis}

$\mathrm{R}$ software (version 3.5.0) was used for statistical analysis. Age did not conform to the normal distribution, so the nonparametric rank-sum test was adopted to test the difference between cases and controls. Categorical data such as gender were evaluated using the chi-square test. The Pearson's chi-square test of the genetics package with $\mathrm{R}$ software was used for Hardy Weinberg Equilibrium (HWE) in the case and control groups. Unconditional logistic regression was used to calculate the odds ratios (ORs) and 95\% confidence intervals (CIs), adjusted for age and gender, for the association of each SNP with the infection of $H$. pylori, the risk of non-cardia gastric cancer, as well as the expression of LATS1 and LATS2 proteins in non-cardia GC tissues, using the codominant, dominant, recessive, overdominant, and logadditive inheritance models, respectively. Haploview 4.2 software was used to conduct LD and haplotype block on the four SNPs of LATS2, calculate the limit of detection value and linkage disequilibrium, and construct haplotype by the D' confidence interval method.

\section{Results \\ General description of the samples}

A total of 808 samples were included in this study, including 381 samples of non-cardia GC (case group) and 427 samples of healthy individuals (control group). The statistical results showed that the age distribution between the case group and the control group was statistical significance. There was no significant difference in gender distribution between the case group and the control group (Table 1).

\section{Association between LATS1 and LATS2 SNPs and risk of $H$.} pylori infection in normal control

Among the 427 normal subjects, 225 cases were negative for $H$. pylori infection and 202 were positive for $H$. pylori infection, with a positive rate of $47.3 \%$. The statistical results showed that there were no significant differences in the age and gender distribution between the $H$. pylori-negative and H. pylori-positive infection groups (Table 2). The genotype distribution of all SNPs was consistent with HWE in the control group. The results showed that LATS2 rs9552315 was associated with infection of $H$. pylori in codominant and dominant models. The dominant genetic model was more suitable with a lower Akaike Information Criterion (AIC) and Bayesian Information Criterion (BIC). No association was found between other SNPs and infection of $H$. pylori (Table 3). Furthermore, no haploid blocks were formed between the four SNPs of LATS2.

\section{Association between LATS1 and LATS2 SNPs and risk of non-cardia GC}

Results showed that LATS1 rs9393175 was associated with the risk of non-cardia GC in codominant, dominant, and overdominant models. The overdominant genetic model 
Table 4 Association between 5 SNPs and risk of non-cardia gastric cancer under different genetic models

\begin{tabular}{|c|c|c|c|c|c|c|c|c|}
\hline Locus & Model & Genotype & Control [n(\%)] & Case $[n(\%)]$ & OR $(95 \% C l)^{a}$ & $P$ & $\mathrm{AIC}$ & $\mathrm{BIC}$ \\
\hline \multirow{10}{*}{$\begin{array}{l}\text { LATS1 } \\
\text { rs9393175 }\end{array}$} & \multirow[t]{3}{*}{ codominant } & $\mathrm{G} / \mathrm{G}$ & $253(59.53)$ & $253(67.29)$ & 1 & - & \multirow[t]{3}{*}{1092.330} & \multirow[t]{3}{*}{1115.760} \\
\hline & & $A / G$ & $149(35.06)$ & $101(26.86)$ & $0.696(0.509-0.949)$ & 0.022 & & \\
\hline & & $\mathrm{A} / \mathrm{A}$ & $23(5.41)$ & $22(11.26)$ & $0.906(0.486-1.683)$ & 0.753 & & \\
\hline & \multirow[t]{2}{*}{ dominant } & $\mathrm{G} / \mathrm{G}$ & $253(59.53)$ & $253(67.29)$ & 1 & - & \multirow[t]{2}{*}{1090.969} & \multirow[t]{2}{*}{1109.713} \\
\hline & & $\mathrm{A} / \mathrm{A}+\mathrm{A} / \mathrm{G}$ & $172(40.47)$ & $123(32.71)$ & $0.725(0.540-0.972)$ & 0.032 & & \\
\hline & \multirow[t]{2}{*}{ recessive } & $\mathrm{G} / \mathrm{G}+\mathrm{A} / \mathrm{G}$ & $402(94.59)$ & 354 (94.15) & 1 & - & \multirow[t]{2}{*}{1095.593} & \multirow[t]{2}{*}{1114.337} \\
\hline & & $\mathrm{A} / \mathrm{A}$ & $23(5.41)$ & $22(5.85)$ & $1.018(0.551-1.877)$ & 0.954 & & \\
\hline & \multirow[t]{2}{*}{ overdominant } & $\mathrm{G} / \mathrm{G}+\mathrm{A} / \mathrm{A}$ & $276(64.94)$ & $275(73.14)$ & 1 & - & \multirow[t]{2}{*}{1090.429} & \multirow[t]{2}{*}{1109.173} \\
\hline & & $\mathrm{A} / \mathrm{G}$ & 149 (35.06) & $101(26.86)$ & $0.702(0.516-0.952)$ & 0.024 & & \\
\hline & log-additive & - & - & - & $0.814(0.641-1.030)$ & 0.088 & 1092.663 & 1111.406 \\
\hline \multirow{10}{*}{$\begin{array}{l}\text { LATS2 } \\
\text { rs558614 }\end{array}$} & \multirow[t]{3}{*}{ codominant } & $\mathrm{T} / \mathrm{T}$ & $123(29.85)$ & $90(23.81)$ & 1 & - & \multirow[t]{3}{*}{1081.499} & \multirow[t]{3}{*}{1104.859} \\
\hline & & $\mathrm{C} / \mathrm{T}$ & $197(47.82)$ & $192(50.79)$ & $1.287(0.916-1.812)$ & 0.147 & & \\
\hline & & $\mathrm{C} / \mathrm{C}$ & $92(22.33)$ & $96(25.40)$ & $1.375(0.923-2.052)$ & 0.118 & & \\
\hline & \multirow[t]{2}{*}{ dominant } & $\mathrm{T} / \mathrm{T}$ & $123(29.85)$ & $90(23.81)$ & 1 & - & \multirow[t]{2}{*}{1079.635} & \multirow[t]{2}{*}{1098.323} \\
\hline & & $\mathrm{C} / \mathrm{C}+\mathrm{C} / \mathrm{T}$ & $289(70.15)$ & 288 (76.19) & $1.315(0.955-1.815)$ & 0.094 & & \\
\hline & \multirow[t]{2}{*}{ recessive } & $\mathrm{T} / \mathrm{T}+\mathrm{C} / \mathrm{T}$ & $320(77.67)$ & $282(74.60)$ & 1 & - & \multirow[t]{2}{*}{1081.613} & 1100.301 \\
\hline & & $\mathrm{C} / \mathrm{C}$ & $92(22.33)$ & $96(25.40)$ & $1.168(0.838-1.628)$ & 0.360 & & \\
\hline & overdominant & $\mathrm{T} / \mathrm{T}+\mathrm{C} / \mathrm{C}$ & $215(52.18)$ & $186(49.21)$ & - & - & 1081.954 & 1100.642 \\
\hline & & $\mathrm{C} / \mathrm{T}$ & $197(47.82)$ & $192(50.79)$ & $1.107(0.834-1.470)$ & 0.480 & & \\
\hline & log-additive & - & - & - & $1.176(0.964-1.436)$ & 0.111 & 1079.912 & 1098.600 \\
\hline LATS2 & codominant & $\mathrm{T} / \mathrm{T}$ & $105(24.82)$ & $100(26.46)$ & 1 & - & 1096.314 & 1119.743 \\
\hline rs9552315 & & $\mathrm{C} / \mathrm{T}$ & $207(48.94)$ & 195 (51.59) & $1.034(0.735-1.456)$ & 0.848 & & \\
\hline & & $\mathrm{C} / \mathrm{C}$ & $111(26.24)$ & $83(21.96)$ & $0.812(0.544-1.212)$ & 0.309 & & \\
\hline & dominant & $\mathrm{T} / \mathrm{T}$ & $105(24.82)$ & $100(26.46)$ & 1 & - & 1096.153 & 1114.896 \\
\hline & & $\mathrm{C} / \mathrm{C}+\mathrm{C} / \mathrm{T}$ & $318(75.18)$ & $278(73.54)$ & $0.956(0.693-1.321)$ & 0.785 & & \\
\hline & recessive & $\mathrm{T} / \mathrm{T}+\mathrm{C} / \mathrm{T}$ & $312(73.76)$ & $295(78.04)$ & 1 & - & 1094.350 & 1113.094 \\
\hline & & $\mathrm{C} / \mathrm{C}$ & $111(26.24)$ & $83(21.96)$ & $0.795(0.570-1.104)$ & 0.172 & & \\
\hline & overdominant & $\mathrm{T} / \mathrm{T}+\mathrm{C} / \mathrm{C}$ & $216(51.06)$ & $183(48.41)$ & 1 & - & 1095.351 & 1114.095 \\
\hline & & $C / T$ & $207(48.94)$ & 195 (51.59) & $1.144(0.863-1.516)$ & 0.350 & & \\
\hline & log-additive & - & - & - & $0.903(0.740-1.102)$ & 0.317 & 1095.226 & 1113.970 \\
\hline LATS2 & codominant & $\mathrm{C} / \mathrm{C}$ & $350(82.74)$ & 302 (79.89) & 1 & - & 1097.992 & 1121.421 \\
\hline & & $\mathrm{C} / \mathrm{T}$ & $67(15.84)$ & $69(18.25)$ & $1.188(0.816-1.729)$ & 0.368 & & \\
\hline & & $\mathrm{T} / \mathrm{T}$ & $6(1.42)$ & $7(1.85)$ & $1.386(0.449-4.402)$ & 0.566 & & \\
\hline & dominant & $\mathrm{C} / \mathrm{C}$ & $350(82.74)$ & 302 (79.89) & 1 & - & 1096.061 & 1114.804 \\
\hline & & $\mathrm{C} / \mathrm{T}+\mathrm{T} / \mathrm{T}$ & $73(17.26)$ & $76(20.11)$ & $1.204(0.839-1.729)$ & 0.314 & & \\
\hline & recessive & $\mathrm{C} / \mathrm{C}+\mathrm{C} / \mathrm{T}$ & $417(98.58)$ & $371(98.15)$ & 1 & - & 1096.804 & 1115.547 \\
\hline & & $\mathrm{T} / \mathrm{T}$ & $6(1.42)$ & $7(1.85)$ & $1.345(0.437-4.264)$ & 0.602 & & \\
\hline & overdominant & $\mathrm{C} / \mathrm{C}+\mathrm{T} / \mathrm{T}$ & $356(84.17)$ & 309 (81.75) & 1 & - & 1096.322 & 1115.065 \\
\hline & & $C / T$ & $67(15.84)$ & $69(18.25)$ & $1.180(0.812-1.717)$ & 0.385 & & \\
\hline & log-additive & - & - & - & $1.185(0.861-1.633)$ & 0.298 & 1095.993 & 1114.736 \\
\hline LATS2 & codominant & $\mathrm{A} / \mathrm{A}$ & $161(37.97)$ & $180(47.24)$ & 1 & - & 1094.648 & 1118.102 \\
\hline & & $A / G$ & $194(45.75)$ & $161(42.26)$ & $0.747(0.552-1.010)$ & 0.058 & & \\
\hline & & $\mathrm{G} / \mathrm{G}$ & $69(16.27)$ & $40(10.50)$ & $0.525(0.333-0.818)$ & 0.005 & & \\
\hline & dominant & $\mathrm{A} / \mathrm{A}$ & 161 (37.97) & $180(47.24)$ & 1 & - & 1095.087 & 1113.850 \\
\hline
\end{tabular}


Table 4 Association between 5 SNPs and risk of non-cardia gastric cancer under different genetic models (Continued)

\begin{tabular}{|c|c|c|c|c|c|c|c|c|}
\hline Locus & Model & Genotype & Control [n(\%)] & Case $[n(\%)]$ & OR $(95 \% C l)^{a}$ & $P$ & AIC & $\mathrm{BIC}$ \\
\hline & & $\mathrm{A} / \mathrm{G}+\mathrm{G} / \mathrm{G}$ & $263(62.03)$ & $201(52.76)$ & $0.688(0.518-0.915)$ & 0.010 & & \\
\hline & \multirow[t]{2}{*}{ recessive } & $A / A+A / G$ & 355 (83.73) & 341 (89.50) & 1 & - & 1096.241 & 1115.004 \\
\hline & & $\mathrm{G} / \mathrm{G}$ & 69 (16.27) & $40(10.50)$ & $0.609(0.397-0.923)$ & 0.021 & & \\
\hline & \multirow[t]{2}{*}{ overdominant } & $\mathrm{A} / \mathrm{A}+\mathrm{G} / \mathrm{G}$ & $230(54.25)$ & $220(57.74)$ & 1 & - & 1100.815 & 1119.578 \\
\hline & & $A / G$ & $194(45.75)$ & $161(42.26)$ & $0.871(0.657-1.156)$ & 0.339 & & \\
\hline & log-additive & - & - & - & $0.731(0.594-0.897)$ & 0.003 & 1092.686 & 1111.449 \\
\hline
\end{tabular}

adjusted for gender and age

was more suitable with the lowest AIC and BIC. LATS2 rs9509492 was associated with the risk of non-cardia GC in the codominant, dominant, recessive, and log-additive models. The log-additive genetic model was more suitable with the lowest AIC and BIC. No associations were found between other SNPs and non-cardia GC (Table 4). Furthermore, no haploid blocks were formed between the four SNPs of LATS2.

\section{Association between five SNPs and expression of LATS1 and LATS2 proteins in non-cardia GC tissues}

We evaluated the expression of LATS1 and LATS2 proteins by immunohistochemistry among the non-cardia GC tissues and normal tissues adjacent to cancer in our pre-study [14]. The results showed that the expression of LATS1 and LATS2 in non-cardia GC tissue was significantly lower than that in normal gastric tissue adjacent to cancer. We analyzed the association between five SNPs and expression of LATS1 or LATS2 proteins in 111 non-cardia GC tissue samples by the logistic regression method in five different genetic models. The results showed that no associations were found (Table 5). Furthermore, no haploid blocks were formed between the four SNPs of LATS2.

\section{Discussion}

$\mathrm{GC}$ is one of the most common malignant tumors with a large number of new cases and deaths every year globally. Asia is a region with a high incidence of GC, accounting for about half of the total number of cases worldwide, while China is one of the countries with a high incidence of GC in Asia. Although the incidence and mortality of GC have been decreasing in recent years, they are still at the forefront of all malignant tumors. According to its anatomical location, GC can be divided into cardia and non-cardia, which have big differences in the mechanism, carcinogenesis, clinical manifestations, treatment, and prognosis. Cardia GC is similar to esophageal cancer regarding clinical characteristics, etiology, and pathology and epidemiology. Therefore, this experiment studied non-cardia GC to avoid sample clinical heterogeneity that could affect the results of the study.
The Hippo signaling pathway is a tumor inhibition pathway that was discovered in recent years, of which LATS1 and LATS2 kinase are two important components and have many important biological functions. LATS1 and LATS2 are involved in the occurrence and development of GC [15].

H. pylori infection is an important factor causing GC. Genome-wide scanning and case-control studies have confirmed that $H$. pylori infection is associated with individual genetic polymorphism [7]. In this study, we found that rs9552315 of LATS2 gene was associated with $H$. pylori infection, and the dominant model was most suitable with the lowest AIC and BIC. Compared with the TT genotype, the $\mathrm{CC}+\mathrm{CT}$ genotype can reduce the risk of $H$. pylori infection. The other four SNPs were not associated with $H$. pylori infection. At present, no correlation analysis between these five SNPs and H. pylori infection has been reported, so our results need to be further verified.

Among the five selected SNPs, rs7317471 and rs9509492 were used to study the mortality of hepatocellular carcinoma (HCC) [16]. The results showed that rs7317471 was associated with mortality from HCC, and rs9509492 was considered to be an independent prognostic indicator of overall survival rate of HCC patients, while rs9509492 was not associated with the mortality of HCC. Moreover, Sebio [17] studied the association between rs558614 and rs9552315 and colorectal cancer, and the results showed that the two SNPs were not associated with the incidence risk of colorectal cancer. In this study, we analyzed the association between five SNPs of LATS1 and LATS2 genes and the risk of noncardia GC. The results showed that LATS1 rs9393175 was associated with the risk of non-cardia GC in an overdominant model which was most suitable with the lowest AIC and BIC. Compared with the GG + AA genotype, carrying the AG genotype may reduce the risk of non-cardia GC. Therefore, the AG genotype may be a protective factor against non-cardia GC in the Baotou Han population. Besides, LATS2 rs9509492 was found to be associated with the risk of non-cardia GC. The logadditive genetic model is most suitable with the lowest AIC and BIC. Furthermore, no associations were found 
Table 5 Association between 5 SNPs and expression of LATS1 and LATS2 under different genetic models

\begin{tabular}{|c|c|c|c|c|c|c|c|c|}
\hline Locus & Model & Genotype & $\begin{array}{l}\text { Positive } \\
\text { expression } \mathrm{N}(\%)\end{array}$ & $\begin{array}{l}\text { Negative } \\
\text { expression } \\
\mathrm{N}(\%)\end{array}$ & OR $(95 \% \mathrm{Cl})^{\mathrm{a}}$ & $P$ & $\mathrm{AIC}$ & $\mathrm{BIC}$ \\
\hline \multirow{10}{*}{$\begin{array}{l}\text { LATS1 } \\
\text { rs9393175 }\end{array}$} & \multirow[t]{3}{*}{ codominant } & $\mathrm{G} / \mathrm{G}$ & $30(62.50)$ & $40(65.57)$ & 1 & - & 157.896 & 171.353 \\
\hline & & $\mathrm{A} / \mathrm{G}$ & $15(31.25)$ & $16(26.23)$ & $1.208(0.508-2.869)$ & 0.667 & & \\
\hline & & A/A & $3(6.25 \%)$ & $5(8.20)$ & $0.795(0.152-3.535)$ & 0.767 & & \\
\hline & \multirow[t]{2}{*}{ dominant } & $\mathrm{G} / \mathrm{G}$ & $30(62.50)$ & $40(65.57)$ & 1 & - & 156.162 & 166.927 \\
\hline & & $\mathrm{A} / \mathrm{A}+\mathrm{A} / \mathrm{G}$ & $18(37.50)$ & $21(34.43)$ & $1.110(0.497-2.467)$ & 0.798 & & \\
\hline & \multirow[t]{2}{*}{ recessive } & $\mathrm{G} / \mathrm{G}+\mathrm{A} / \mathrm{G}$ & $45(93.75)$ & $56(91.80)$ & 1 & - & 156.082 & 166.847 \\
\hline & & A/A & $3(6.25)$ & $5(8.20)$ & $0.750(0.146-3.258)$ & 0.706 & & \\
\hline & \multirow[t]{2}{*}{ overdominant } & $\mathrm{G} / \mathrm{G}+\mathrm{A} / \mathrm{A}$ & $33(68.75)$ & $45(73.77)$ & 1 & - & 155.985 & 166.751 \\
\hline & & $A / G$ & $15(31.25)$ & $16(26.23)$ & $1.237(0.527-2.897)$ & 0.623 & & \\
\hline & log-additive & - & - & - & $1.012(0.544-1.863)$ & 0.970 & 156.225 & 166.991 \\
\hline \multirow{10}{*}{$\begin{array}{l}\text { LATS2 } \\
\text { rs558614 }\end{array}$} & \multirow[t]{3}{*}{ codominant } & $\mathrm{T} / \mathrm{T}$ & $20(26.67)$ & $6(17.14)$ & 1 & - & 144.846 & 158.348 \\
\hline & & $C / T$ & $35(46.67)$ & $21(60.00)$ & $0.505(0.163-1.407)$ & 0.208 & & \\
\hline & & $\mathrm{C} / \mathrm{C}$ & $20(26.67)$ & $8(22.86)$ & $0.739(0.208-2.522)$ & 0.630 & & \\
\hline & \multirow[t]{2}{*}{ dominant } & $\mathrm{T} / \mathrm{T}$ & $20(26.67)$ & $6(17.14)$ & 1 & - & 143.431 & 154.233 \\
\hline & & $\mathrm{T} / \mathrm{C}+\mathrm{C} / \mathrm{C}$ & 55 (73.33) & $29(82.86)$ & $0.570(0.190-1.513)$ & 0.280 & & \\
\hline & \multirow[t]{2}{*}{ recessive } & $\mathrm{T} / \mathrm{T}+\mathrm{C} / \mathrm{T}$ & $55(73.33)$ & $27(77.14)$ & 1 & - & 144.519 & 155.321 \\
\hline & & $\mathrm{C} / \mathrm{C}$ & $20(26.67)$ & $8(22.86)$ & $1.200(0.478-3.229)$ & 0.705 & & \\
\hline & \multirow[t]{2}{*}{ overdominant } & $\mathrm{C} / \mathrm{C}+\mathrm{T} / \mathrm{T}$ & $40(53.33)$ & $14(40.00)$ & 1 & - & 143.079 & 153.881 \\
\hline & & $C / T$ & $35(46.67)$ & $21(60.00)$ & $0.593(0.258-1.336)$ & 0.211 & & \\
\hline & log-additive & - & - & - & $0.882(0.491-1.572)$ & 0.670 & 144.483 & 155.285 \\
\hline \multirow{10}{*}{$\begin{array}{l}\text { LATS2 } \\
\text { rs9552315 }\end{array}$} & \multirow[t]{3}{*}{ codominant } & $\mathrm{T} / \mathrm{T}$ & $25(33.33)$ & 7 (20.59) & 1 & - & 141.158 & 154.615 \\
\hline & & $C / T$ & $31(41.33)$ & $20(58.82)$ & $0.409(0.139-1.100)$ & 0.087 & & \\
\hline & & $\mathrm{C} / \mathrm{C}$ & $19(25.33)$ & $7(20.59)$ & $0.716(0.207-2.451)$ & 0.591 & & \\
\hline & \multirow[t]{2}{*}{ dominant } & $\mathrm{T} / \mathrm{T}$ & $25(33.33)$ & $7(20.59)$ & 1 & - & 140.308 & 151.073 \\
\hline & & $\mathrm{T} / \mathrm{C}+\mathrm{C} / \mathrm{C}$ & $50(66.67)$ & $27(79.41)$ & $0.489(0.174-1.244)$ & 0.149 & & \\
\hline & \multirow[t]{2}{*}{ recessive } & $\mathrm{T} / \mathrm{T}+\mathrm{C} / \mathrm{T}$ & $56(74.67)$ & $27(79.41)$ & 1 & - & 142.279 & 153.044 \\
\hline & & $\mathrm{C} / \mathrm{C}$ & $19(25.33)$ & $7(20.59)$ & $1.283(0.493-3.632)$ & 0.621 & & \\
\hline & \multirow[t]{2}{*}{ overdominant } & $\mathrm{C} / \mathrm{C}+\mathrm{T} / \mathrm{T}$ & $44(58.67)$ & $14(41.18)$ & 1 & - & 139.447 & 150.213 \\
\hline & & $C / T$ & $31(41.33)$ & $20(58.82)$ & $0.478(0.205-1.089)$ & 0.082 & & \\
\hline & \multirow[t]{3}{*}{ log-additive } & - & - & - & $0.836(0.473-1.468)$ & 0.533 & 142.140 & 152.905 \\
\hline \multirow{2}{*}{$\begin{array}{l}\text { LATS2 } \\
\text { rs7317471 }\end{array}$} & & $\mathrm{C} / \mathrm{C}$ & $63(85.14)$ & $26(74.29)$ & 1 & - & 142.226 & 152.992 \\
\hline & & $C / T$ & $11(14.86)$ & $9(25.71)$ & $0.509(0.186-1.413)$ & 0.187 & & \\
\hline \multirow{10}{*}{$\begin{array}{l}\text { LATS2 } \\
\text { rs9509492 }\end{array}$} & \multirow[t]{3}{*}{ codominant } & A/A & $34(45.33)$ & $16(44.44)$ & 1 & - & 147.894 & 161.441 \\
\hline & & $A / G$ & $32(42.67)$ & $18(50.00)$ & $0.842(0.364-1.936)$ & 0.686 & & \\
\hline & & $\mathrm{G} / \mathrm{G}$ & $9(12.00)$ & $2(5.56)$ & $2.138(0.478-15.146)$ & 0.366 & & \\
\hline & \multirow[t]{2}{*}{ dominant } & A/A & $34(45.33)$ & $16(44.44)$ & 1 & - & 147.305 & 158.143 \\
\hline & & $\mathrm{A} / \mathrm{G}+\mathrm{G} / \mathrm{G}$ & $41(54.67)$ & $20(55.56)$ & $0.972(0.433-2.167)$ & 0.945 & & \\
\hline & \multirow[t]{2}{*}{ recessive } & $\mathrm{A} / \mathrm{A}+\mathrm{A} / \mathrm{G}$ & $66(88.00)$ & $34(94.44)$ & & - & 146.058 & 156.896 \\
\hline & & $\mathrm{G} / \mathrm{G}$ & $9(12.00)$ & $2(5.56)$ & $2.332(0.559-15.911)$ & 0.297 & & \\
\hline & \multirow[t]{2}{*}{ overdominant } & $\mathrm{A} / \mathrm{A}+\mathrm{G} / \mathrm{G}$ & $43(57.33)$ & $18(50.00)$ & 1 & - & 146.805 & 157.644 \\
\hline & & $A / G$ & $32(42.67)$ & $18(50.00)$ & $0.748(0.334-1.670)$ & 0.478 & & \\
\hline & log-additive & - & - & - & $1.147(0.623-2.160)$ & 0.662 & 147.118 & 157.956 \\
\hline
\end{tabular}


between LATS2 SNPs rs558614, rs9552315, rs7317471 and risk of non-cardia GC. To the best of our knowledge, this is the first report of associations between these five SNPs and non-cardia GC, so our experimental results need further confirmation.

Furthermore, the relationship between polymorphisms in the LATS1 and LATS2 genes and their protein expression levels were analyzed. However, no correlations were found between these five SNPs and their protein expression levels, suggesting that gene mutations at five loci of the two genes may not affect their protein expression levels. It is also possible that these five SNPs had small effects on protein expression levels that were not detected due to the small sample size of only 111 noncardia GC tissue samples. Therefore, our experimental results need to be further confirmed by expanding the sample size.

There are several limitations to our study. Firstly, we recruited non-cardia gastric cancer cases from one hospital and selected normal controls from another two hospitals, which might not be representative of the general population and resulted in potential selection bias. Secondly, although the infection of $H$. pylori was correlated with non-cardia gastric cancer risk, it is difficult to measure H. pylori infection in gastric cancer patients. Gastric cancer is a multigenic disease, and patients generally develop into gastric cancer through chronic atrophic gastritis, intestinal metaplasia, low-level neoplasia, high-level neoplasia stages. H. pylori lose its colonized soil in atrophic body gastritis and disappear slowly during gastric carcinogenesis $[18,19]$. Moreover, in a long disease progression, most patients were treated with the antibiotic, which resulted in the loss of $H$. pylori. Lack of available information on $H$. pylori infection status in patients with non-cardia gastric cancer limited us to adjust the potential confounding bias of this risk factor.

\section{Conclusions}

In this experiment, our group studied the association between these five SNPs and $H$. pylori infection and explored the association between LATS1 and LATS2 SNPs and non-cardiac GC for the first time, to the best of our knowledge. The results of this study indicated that some SNPs of the LATS1 and LATS2 genes were involved in the pathogenesis of $H$. pylori infection and non-cardia GC, of which LATS2 rs9552315 was associated with $H$. pylori infection. Besides, compared with the TT genotype, the $\mathrm{CC}+\mathrm{CT}$ genotype appeared to reduce the risk of $H$. pylori infection and may be a protective factor against $H$. pylori infection in the Baotou Han population. LATS1 rs9393175 and LATS2 rs9509492 were associated with the risk of non-cardia GC, and AG and GG genotypes may be protective factors against GC in the Baotou Han population. These two SNPs may become biomarkers for GC screening and provide a new approach for the targeted therapy of GC. However, non-cardia GC patients and normal control samples were from the Han population in Baotou, Inner Mongolia, so the results only represent the genetic characteristics of the Han population in this area, and the sample size was also low. In the future, other regions and other ethnic groups need to be studied, and the sample size should be expanded to further clarify the relationship between these five SNPs and H. pylori infection and non-cardia GC.

\section{Abbreviations \\ LATS1: Large tumor suppressor kinase 1; LATS2: Large tumor suppressor kinase 2; GC: Gastric cancer; SNP: Single nucleotide polymorphism; $H$. pylori: Helicobacter pylori; ELISA: Enzyme-linked immunosorbent assay; OR: Odds ratio; Cl: Confidence interval; HWE: Hardy Weinberg Equilibrium; AIC: Akaike Information Criterion; BIC: Bayesian Information Criterion; HCC: Hepatocellular carcinoma}

\section{Acknowledgements}

None.

\section{Authors' contributions}

Conception and design: MLC, TXY, DT, JYB; data collection: MLC, TXY, DWJ; Molecular biology experiment: MLC, TXY, GF; data analysis and interpretation: MLC, TXY; manuscript writing: MLC, TXY; manuscript revision: JYB and DT; final approval of manuscript: All authors.

\section{Funding}

This study was supported by the National Natural Science Foundation of China (No. 81250024, 81650017); the Natural Science Foundation of Inner Mongolia (2016MS0805); the Scientific Research Fund of Baotou Medical College (BYJJ-DF-201603, BYJJ-YF-2018023, BYJJ-QM-2018024); Science and Technology Planning Project of Baotou City (2019Z3011-01). The funding bodies had a role in study design, data collection, analysis and decision to publish and preparation of the manuscript.

\section{Availability of data and materials}

The datasets generated and analyzed during the present study are available from the corresponding author on reasonable request. All data generated or analyzed during this study are included in this published article.

Ethics approval and consent to participate

At recruitment, written informed consent was obtained from each subject. Our study complies with the Code of Ethics of the World Medical Association (Declaration of Helsinki) and the study was approved by the Institutional Review Board of Baotou Medical College.

Consent for publication

Not applicable.

Competing interests

The authors declare that they have no competing interests.

\section{Author details}

${ }^{1}$ Inner Mongolia Institute of Digestive Diseases, The Second Affiliated Hospital of Baotou Medical College, 30 Hudemulin Street, Baotou 014030, Inner Mongolia, China. ${ }^{2}$ Pathology Department, the Second Affiliated Hospital of Baotou Medical College, Baotou 014030, Inner Mongolia, China. ${ }^{3}$ School of Basic Medicine and Forensic Medicine, Baotou Medical College, Baotou 014060, Inner Mongolia, China. ${ }^{4}$ School of Medical Technology, Baotou Medical College, Baotou 014060, Inner Mongolia, China. ${ }^{5}$ School of Nursing, Baotou Medical College, 31 Jianshe Road, Baotou 014060, Inner Mongolia, China. 
Received: 17 November 2019 Accepted: 30 March 2020

Published online: 18 May 2020

\section{References}

1. Bray F, Ferlay J, Soerjomataram I, Siegel RL, Torre LA, Jemal A. Global cancer statistics 2018: GLOBOCAN estimates of incidence and mortality worldwide for 36 cancers in 185 countries. CA Cancer J Clin. 2018;68(6):394-424.

2. Lu B, Li M. Helicobacter pylori eradication for preventing gastric cancer. World J Gastroenterol. 2014;20(19):5660-5.

3. Schistosomes, liver flukes and Helicobacter pylori. IARC Working Group on the Evaluation of Carcinogenic Risks to Humans. Lyon, 7-14 June 1994. IARC Monogr Eval Carcinog Risks Hum. 1994;61:1-241.

4. de Martel C, Ferlay J, Franceschi S, Vignat J, Bray F, Forman D, et al. Global burden of cancers attributable to infections in 2008: a review and synthetic analysis. Lancet Oncol. 2012;13(6):607-15.

5. Wang F, Meng W, Wang B, Qiao L. Helicobacter pylori-induced gastric inflammation and gastric cancer. Cancer Lett. 2014;345(2):196-202.

6. Wroblewski LE, Peek RM Jr, Wilson KT. Helicobacter pylori and gastric cancer: factors that modulate disease risk. Clin Microbiol Rev. 2010;23(4): 713-39.

7. Xiao FK, Yang JX, Li XM, Zhao XK, Zheng PY, Wang LD. Interaction of 22 risk SNPs with helicobacter pylori infection and risk of gastric cardia adenocarcinoma. Future Oncol. 2019;15(31):3579-85.

8. Xu T, Wang W, Zhang S, Stewart RA, Yu W. Identifying tumor suppressors in genetic mosaics: the Drosophila lats gene encodes a putative protein kinase. Development. 1995;121(4):1053-63.

9. Ji XY, Zhong G, Zhao B. Molecular mechanisms of the mammalian hippo signaling pathway. Yi Chuan. 2017;39(7):546-67.

10. Pan D. The hippo signaling pathway in development and cancer. Dev Cell. 2010;19(4):491-505.

11. Wang Y, Yu A, Yu FX. The hippo pathway in tissue homeostasis and regeneration. Protein Cell. 2017;8(5):349-59.

12. Xu B, Sun D, Wang Z, Weng H, Wu D, Zhang $X$, et al. Expression of LATS family proteins in ovarian tumors and its significance. Hum Pathol. 2015; 46(6):858-67.

13. Malik SA, Khan MS, Dar M, Hussain MU, Shah MA, Shafi SM, et al. Molecular alterations and expression dynamics of LATS1 and LATS2 genes in nonsmall-cell lung carcinoma. Pathol Oncol Res. 2018;24(2):207-14.

14. Ma L, Tian X, Gao F, Liu D, Dang T, Bai X, et al. Expressions of large tumor suppressor kinase 1 and large tumor suppressor kinase 2 in gastric cancer and their significances. Cancer Research and Clinic. 2019;31(2):93-7.

15. Kim SH, Jin H, Meng RY, Kim DY, Liu YC, Chai OH, et al. Activating Hippo Pathway via Rassf1 by Ursolic Acid Suppresses the Tumorigenesis ofGastric Cancer. Int J Mol Sci. 2019;20(19):4709.

16. Shen L, Wen J, Zhao T, Hu Z, Song C, Gu D, et al. A genetic variant in large tumor suppressor kinase 2 of hippo signaling pathway contributes to prognosis of hepatocellular carcinoma. Onco Targets Ther. 2016;9:1945-51.

17. Sebio A, Matsusaka S, Zhang W, Yang D, Ning Y, Stremitzer S, et al. Germline polymorphisms in genes involved in the hippo pathway as recurrence biomarkers in stages II/II colon cancer. Pharm J. 2016;16(4): 312-9.

18. Karnes WE Jr, Samloff IM, Siurala M, Kekki M, Sipponen P, et al. Positive serum antibody and negative tissue staining for helicobacter pylori in subjects with atrophic body gastritis. Gastroenterology. 1991;101(1):167-74.

19. Farinati F, Valiante F, Germana B, Della Libera G, Baffa R, Rugge M, et al. Prevalence of helicobacter pylori infection in patients with precancerous changes and gastric cancer. Eur J Cancer Prev. 1993;2(4):321-6.

\section{Publisher's Note}

Springer Nature remains neutral with regard to jurisdictional claims in published maps and institutional affiliations.

Ready to submit your research? Choose BMC and benefit from:
- fast, convenient online submission
- thorough peer review by experienced researchers in your field
- rapid publication on acceptance
- support for research data, including large and complex data types
- gold Open Access which fosters wider collaboration and increased citations
- maximum visibility for your research: over 100M website views per year
At BMC, research is always in progress.
Learn more biomedcentral.com/submissions

